\title{
Opportunities and Challenges of the U.S. Dollar as an Increasingly Global Currency: A Federal Reserve Perspective
}

\begin{abstract}
Michael J. Lambert and Kristin D. Stanton, of the Board's Division of Reserve Bank Operations and Payment Systems, prepared this article.
\end{abstract}

Over the past two decades, demand for U.S. currency, especially the proportion estimated to be held abroad, has increased markedly. As a result, U.S. bank notes are now the most widely recognized and used currency in the world. Businesses and households outside the United States have long held U.S. currency for savings, especially during times of crisis. Over time, businesses and households abroad are increasingly turning to dollars for transactions purposes.

The rapid growth of demand for U.S. currency has posed challenges for the Federal Reserve in meeting its congressionally mandated responsibilities for currency availability and distribution.' Those challenges lie in making certain that the Bureau of Engraving and Printing (BEP) prints adequate amounts of currency; that overseas distribution channels have sufficient capacity to distribute U.S. currency when and where it is needed; and that the integrity of U.S. currency is maintained by monitoring counterfeiting activity. In the process of meeting these challenges, the Federal Reserve has improved its methods of forecasting demand for U.S. currency, expanded currency distribution channels, and worked with the BEP and the U.S. Secret Service to protect against counterfeiting threats.

This article gives an overview of the evolution of the Federal Reserve's responsibilities for U.S. currency, particularly in relation to the increase in foreign demand over the past two decades. It also discusses work on counterfeit deterrence and concludes with a briefinote on the future of currency and coin.

1. The Federal Reserve Act of 1913 established the Board of Governors and the twelve Federal Reserve Banks as the nation's central bank and provided that the Federal Reserve function as monetary authority to establish and issue currency for the United States. By 1920 , the Federal Reserve's role had expanded, as the Department of the Treasury closed Subtreasuries around the country and delegated responsibilities for distributing currency and coin to the Federal Reserve Banks.

\section{DEMAND FOR U.S. CURRENCY}

The Federal Reserve measures demand for U.S. currency by the amount of currency in circulation.? From 1980 to 1998, currency in circulation increased an average of 8 percent per year-from $\$ 124.8$ billion to $\$ 492.2$ billion. In December 1999 , in preparation for the century date change, currency in circulation increased 22.1 percent from its December 1998 level, to $\$ 601.2$ billion. Uncertainty associated with the century date change increased the public's precautionary demand for cash, but as the event passed without incident, the public returned much of the currency it had amassed to depository institutions. Depository institutions, in turn, returned excess currency to the Reserve Banks. Thus, in the first quarter of 2000, the Reserve Banks received record levels of currency from depository institutions, and currency in circulation declined to $\$ 535.4$ billion, a level more consistent with the historical trend (chart 1 ). ${ }^{3}$

Domestic demand for currency is largely based on the use of currency for transactions and is influenced primarily by income levels, prices for goods and services, the availability of alternative payment methods, and the opportunity cost of holding currency in lieu of an interest-bearing asset. In the United States, demand (in terms of number of notes) for smaller denominations ( $\$ 1 \mathrm{~s}$ through $\$ 20 \mathrm{~s}$ ) exceeds demand for larger denominations ( $\$ 50 \mathrm{~s}$ and $\$ 100 \mathrm{~s}$ ). Consumers frequently use smaller-denomination notes for small transactions and alternative payment methods (for example, checks and credit cards) for large purchases.

In contrast, foreign demand is influenced primarily by the political and economic uncertainties associated with certain foreign currencies, which contrast with the U.S. dollar's high degree of stability. The

2. Currency in circulation is the public's cash holdings and depository institutions" vault cash; it excludes Federal Reserve and BEP vault cash.

3 . In the first quarter of 2000 , Federal Reserve Banks received 9.3 billion notes, compared with 6.8 billion notes during the same period in 1999 
1. Currency in circulation, June 1997-May 2001

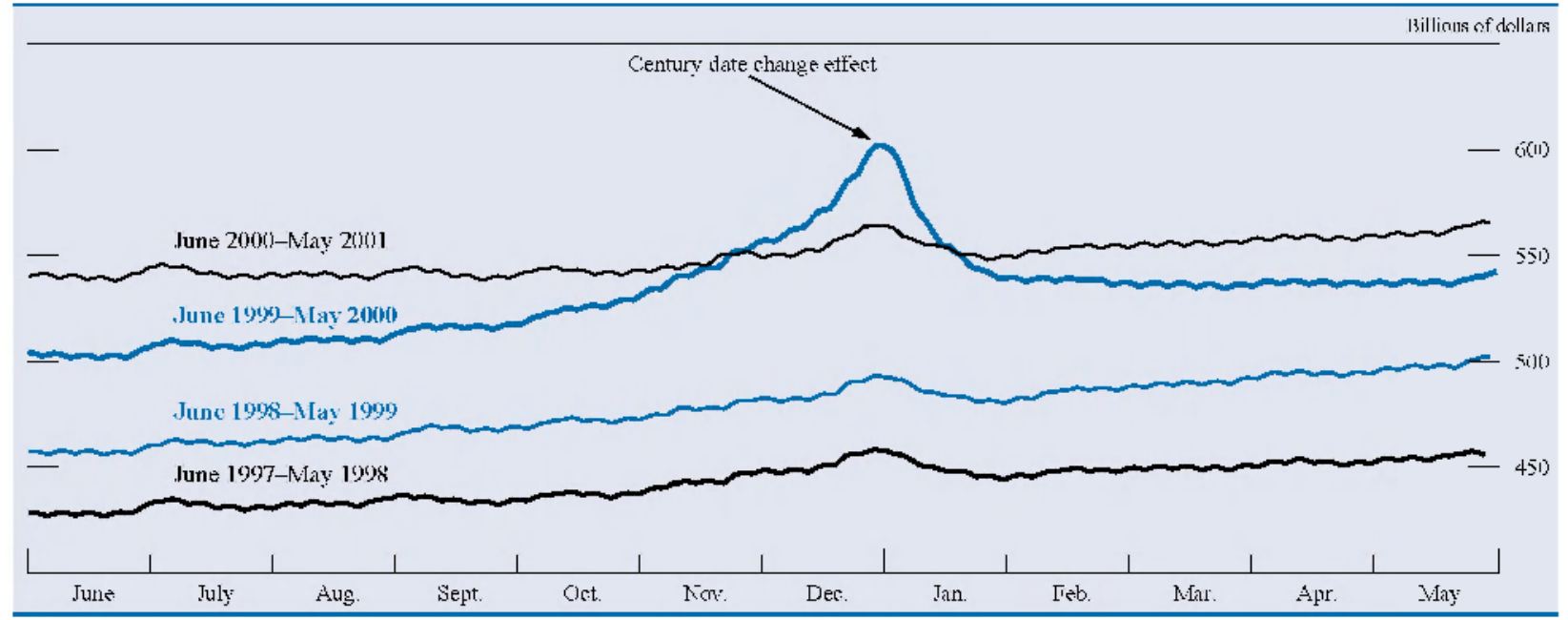

Note. The data are daily. For the definition of currency in circulation, see text note 2 .

dollar remains a stable currency backed by a highly productive economy with low inflation and by the assurance that it will not be demonetized, recalled, or devalued.+ Because U.S. currency is held abroad primarily as savings, foreigners tend to hold highdenomination notes. According to one estimate, about three-fourths of $\$ 100$ notes in circulation are held outside the United States. ${ }^{5}$

The foreign component of the amount of currency in circulation is estimated to have increased significantly beginning in the late $1980 \mathrm{~s}$ and continued to grow through most of the 1990s (chart 2). ${ }^{6}$ Because about 90 percent, on average, of the $\$ 100$ notes ordered by the Federal Reserve Bank of New York appear to be paid out to foreign banking organizations to satisfy foreign demand, net payments (that is, shipments to depository institutions in excess of receipts from depository institutions) of $\$ 100$ notes from the Federal Reserve Bank of New York form one basis for estimating international demand. Based

4. Porter and Judson argue that the dollar's nearly unchanging physical appearance and the U.S. policy of never recalling older-series notes, in addition to the extraordinary strength and stability of the U.S. economy and the dollar, have given rise to near-universal recognition and acceptance of dollars. See Richard D. Porter and Ruth A. Judson, "Overseas Dollar Holdings: What Do We Know?" Wirtschaftspolitische Blätter (April 2001), pp. 431-40.

5. See Richard D. Porter and Ruth A. Judson, "The Location of U.S. Currency: How Much is Abroad?" Federal Reserve Bulletin, vol. 82 (October 1996), pp. 883-903.

6. As opposed to the overall issuance of currency, the amount held abroad must be inferred from a variety of sources, including reports from currency shipments, the denomination of bank notes, and evolving seasonal patterns. Porter and Judson use several methods for estimating the foreign component of total U.S. currency in circulation. The current foreign estimates range from one-half to two-thirds of the total value of currency in circulation. See Porter and Judson, "The Location of U.S. Currency." on estimates of net payments, international demand for U.S. currency increased 219 percent from 1989 to 1990 during the Gulf War. As another example, from 1993 to 1994 international net payments increased 24 percent during the Mexican peso crisis (chart 3). ${ }^{7}$

Other countries have induced their residents to substitute from the local currency to U.S. dollars, both as a store of value and as a medium for transactions. In the extreme, some governments have adopted the dollar as legal tender. Schuler and Stein categorize this process of dollarization as official, semiofficial, or unofficial. According to this classification, official dollarization, also known as full dollarization, occurs when a country adopts the U.S. dollar as both legal tender and as its predominant-or exclusive-currency. ${ }^{8}$ Recent examples of officially dollarized countries include Ecuador (January 2000), El Salvador (January 2001), and Guatemala (May 2001); other countries, such as Panama (1904), have been dollarized for many years. Schuler and Stein define semiofficial dollarization as the use of U.S. dollars as legal tender, while both the local currency and U.S. currency are used in daily transactions. Examples of countries with semiofficial dollarization include the Bahamas, Cambodia, and Haiti. Finally, unofficial dollarization occurs when citizens of a

7. Federal Reserve net payments data suggest that in both episodes, the dollars were returned to the United States after a relatively short period.

8. See Kurt Schuler and Robert Stein, "The International Monetary Stability Act: An Analysis" (paper for the North-South Institute Conference, "To Dollarize or Not to Dollarize?" Ottawa, October 5, 2000). Schuler and Stein define legal tender as currency that is legally acceptable as payment for all debts and differs from forced tender, which requires that people accept a currency in payment even if they would prefer another currency. 


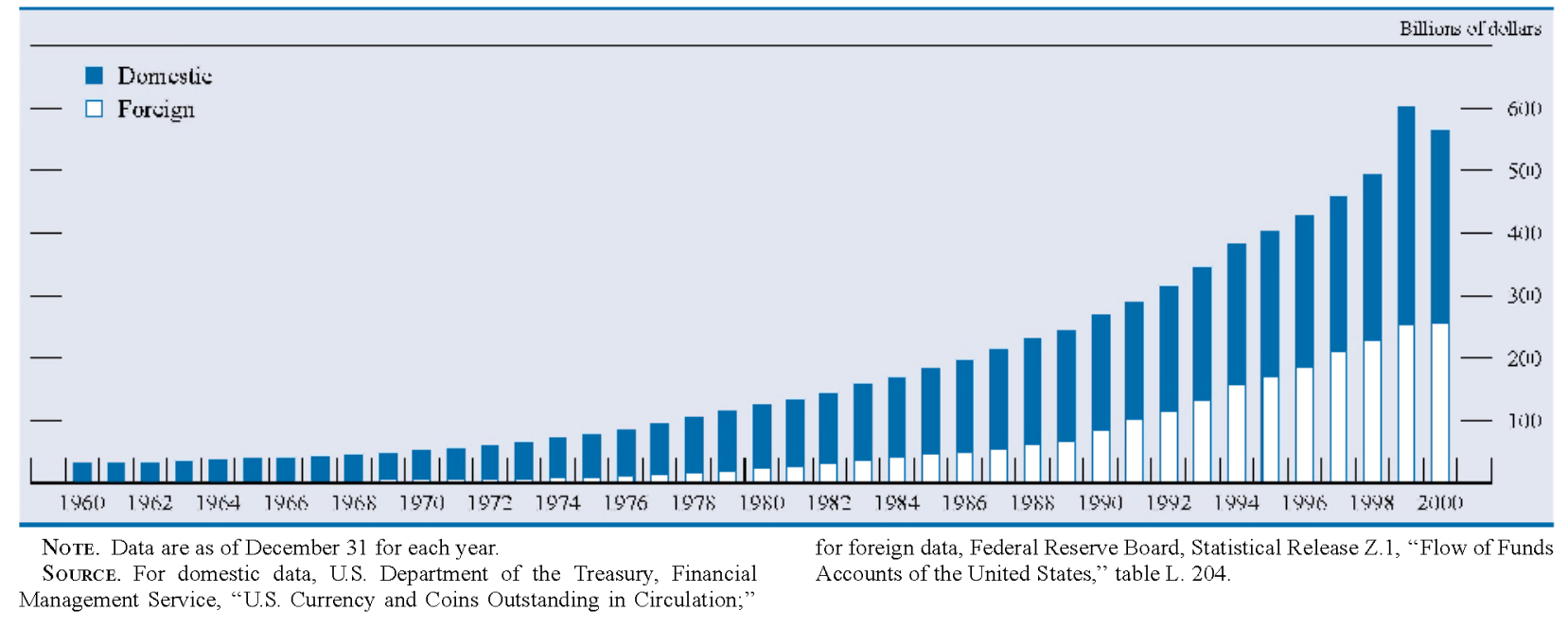

country hold a portion of their financial wealth in U.S. dollars even if U.S. currency is not legal tender (or even legal to use at all). Some unofficially dollarized countries hold and use large amounts of dollars; others hold relatively small amounts. ${ }^{9}$

The decision to dollarize is made by the government and residents of a country based on its own political and economic circumstances. If a country decides to dollarize, the Federal Reserve stands ready to supply currency to or receive currency from that country, although most of the actual shipments are effected through commercial banking channels.

9. For a comprehensive list of dollarized countries, see Schuler and Stein, "The International Monetary Stability Act."

\section{Net international payments of U.S. currency, 1980-2000}

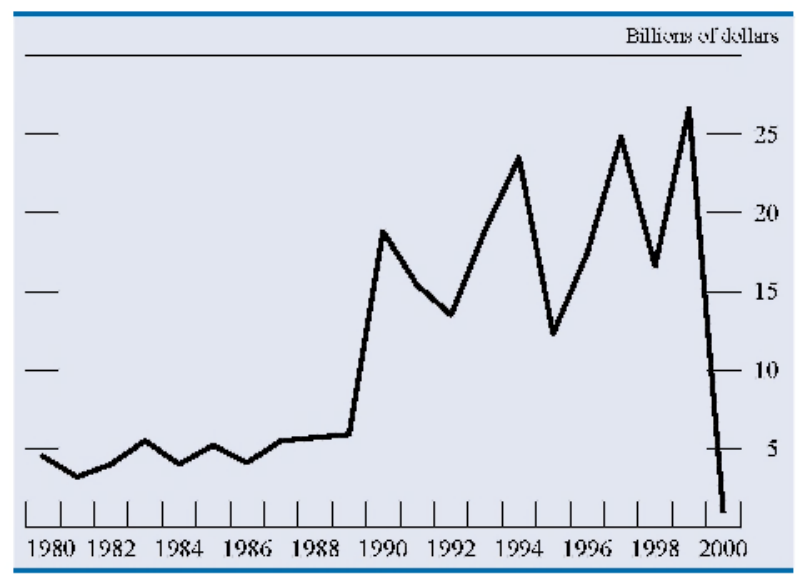

NoTE. The dramatic decline in net international payments in 2000 largely reflects the flow back to the Reserve Banks of excess currency amassed during the century date change period.

Source. Federal Reserve Board, Statistical Release Z.1, "Flow of Funds Accounts of the United States," table F. 204.

\section{FEDERAL RESERVE RESPONSIBILITIES FOR CURRENCY}

Before passage of the Federal Reserve Act, currency in circulation could not always accommodate changes in demand that arose from seasonal and cyclical factors and from periods of financial crisis. The supply of currency was limited because the various forms of Department of the Treasury currency (U.S. notes, Treasury notes of 1890 , and gold and silver certificates) were fixed by statute or governed by the amount of gold and silver held by the Department of the Treasury. The volume of national bank notes was dependent on the decisions of individual national banks; therefore, it was sensitive to liquidity strains during financial crises.

To remedy this problem, the Congress passed the Federal Reserve Act, which mandated an elastic currency that would expand and contract based on public demand. As the public's demand for currency changed, depository institutions would either order currency from or deposit currency with the Federal Reserve Banks. Each Federal Reserve Bank and Branch was located to facilitate the exchange of currency as needed to and from the depository institutions throughout the United States based on the distribution of the population and economic activity when the Federal Reserve was founded. ${ }^{10}$

10. In 1920, the Congress directed the Secretary of the Treasury to discontinue Subtreasuries and the exercise of all duties and functions by the Assistant Treasurers in charge of the offices. The provisions of the Appropriations Act of 1920 authorized the Secretary to delegate the currency and coin functions of the Subtreasuries to the Federal Reserve Banks. 


\section{Forecasting the Demand for Currency}

In addition to requiring an elastic currency, the Federal Reserve Act also authorizes the Federal Reserve to issue Federal Reserve notes to depository institutions through the Federal Reserve Banks. As the nation's issuing authority for U.S. currency, the Federal Reserve Board prepares and submits an annual order to the BEP. The order represents the Federal Reserve System's estimate of the amount of currency that the public will demand in the upcoming year and reflects estimated changes in currency usage and destruction rates of unfit currency."

Staff members of each Federal Reserve Bank cash office and at the Federal Reserve Board collaborate to develop estimates of the demand for currency. In making their estimates, the Reserve Banks consider local economic and environmental conditions that affect demand for currency. Environmental conditions, which vary across the nation, influence the physical appearance of bank notes and how quickly they are soiled, worn, or torn. Each Reserve Bank assesses these conditions in its District to determine the amount of currency needed to meet daily payments to the public and to maintain a safety stock to meet natural contingencies that might disrupt normal distribution channels. Board staff members study Federal Reserve data to reconcile variations and evaluate trends, consider the amount of currency held in vaults at the BEP and at the Reserve Banks, and calculate overall growth rates of net payments and currency destruction rates. Board staff members com-

11. The Federal Reserve, under delegated authority from the Department of the Treasury, is responsible for destroying all unfit currency. The Office of Currency Standards oversees Federal Reserve compliance with Treasury policies and procedures that govern the destruction of currency by conducting regular audits of the cash offices at the Federal Reserve Banks. pare their currency demand estimates with Reserve Bank forecasts and reconcile differences until a consensus print order is approved by the Board.

Once the print order is approved, the Board submits it to the BEP. Based on the number of notes in the order, the BEP determines the unit cost for each denomination. ${ }^{12}$ In 2000, the Federal Reserve paid $\$ 423.4$ million to the BEP to print nearly 9 billion notes (chart 4).

\section{Distribution of Currency}

The Federal Reserve distributes U.S. currency throughout the United States and to all regions of the world through banking channels. Accordingly, the Federal Reserve Banks provide cash services to more than 10,000 of the 21,000 banks, savings and loan institutions, and credit unions in the United States. (See box "Coin Operations at the Federal Reserve.") The remaining institutions obtain cash through their correspondent banks rather than directly from the Federal Reserve. When a depository institution orders currency from a Federal Reserve Bank, the Reserve Bank provides the requested shipment to an armored carrier arranged by the depository institution and charges the depository institution's account with the Federal Reserve (or the account of a depository institution that acts as the ordering depository institution's settlement agent) for the amount of the order. Similarly, when a depository institution returns excess or unfit currency to the Federal Reserve, its account is credited.

Before 1996, commercial banks overseas ordered U.S. currency through bank-note dealers that, in turn,

12. Unit cost is higher for smaller print orders because of fixed production costs at the Washington, D.C., and Ft. Worth, Tex., facilities.

\section{Print order volume and cost of printing Federal Reserve notes, 1986-2000}

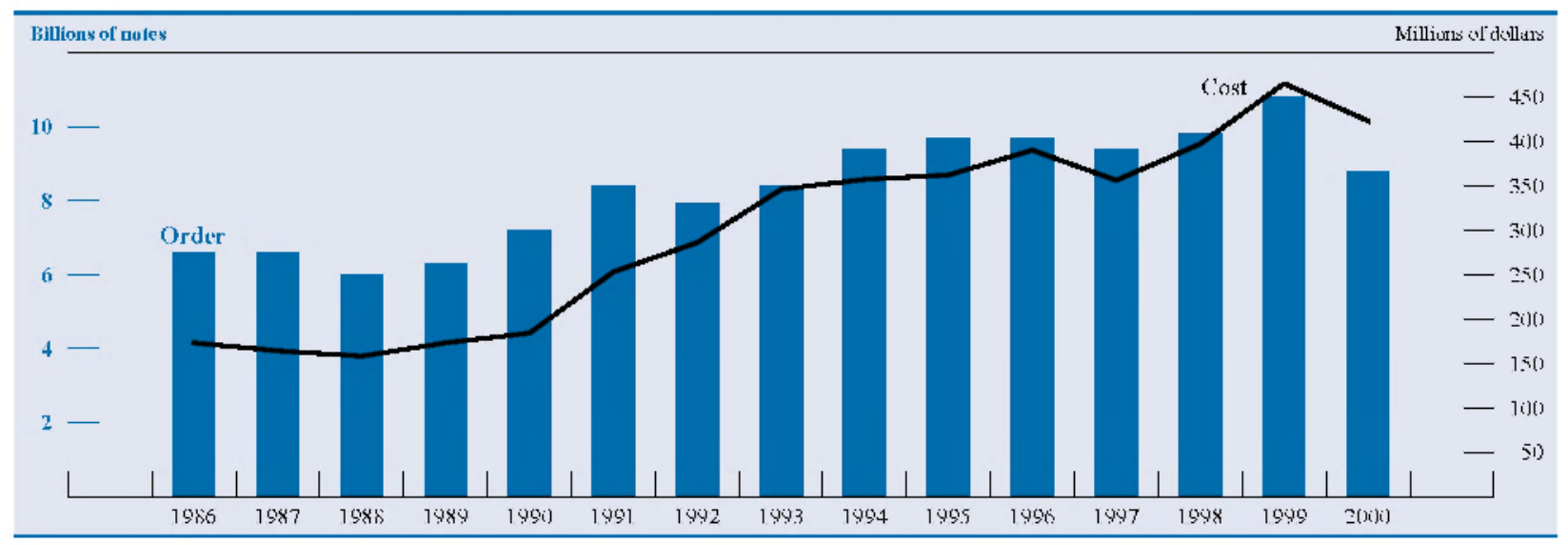




\section{Coin Operations at the Federal Reserve}

The Federal Reserve has a more limited role in coin operations than it has in currency operations. The U.S. Mint determines annual coin production and monitors Federal Reserve coin inventories weekly to identify trends in coin demand

To help the Mint plan for future production, the Reserve Banks provide the Mint with projected monthly coin orders for each fiscal year. The Mint distributes coin to the Reserve Banks from the Philadelphia and Denver production facilities, and the Federal Reserve Banks distribute coin to depository institutions as needed.

In addition to the 37 cash offices, the Reserve Banks also use 116 coin terminals to manage the Federal Reserve's coin volume. Generally, armored carrier companies operate the coin terminals. The armored carriers wrap coin to meet the needs of depository institutions and retailers. As with currency, depository institutions order and deposit coin to meet customer demand.

ordered currency directly from the Federal Reserve Banks (primarily the Federal Reserve Bank of New York). In 1996, the Board approved the Extended Custodial Inventory (ECI) program to facilitate the introduction of the new Series-1996 \$100 note internationally. The ECIs were established in London, Zurich, and Frankfurt to provide currency services for Europe, the Middle East, Africa, and Russia. Because of its success, the Federal Reserve expanded the scope of the program to facilitate the international distribution of future-series U.S. bank notes and the repatriation of old-series notes, to promote an international market for fit U.S. bank notes, and to strengthen U.S. information gathering on the foreign use of U.S. currency and sources of international counterfeiting. In part because of the success of the European ECIs, the Federal Reserve expanded the program to Asia and to South America.

The ECI program allows selected depository institutions to hold currency in their vaults but to carry the inventory on the books of the Federal Reserve Bank of New York. ${ }^{13}$ The Federal Reserve selects commercial banks to act as ECIs through a competitive bidding process. The ECIs receive deposits from depository institutions, sort them into old- and newseries notes, and further sort the new-series notes into bundles (1,000 notes) according to whether the notes are fit or unfit. The ECIs return the old-series and unfit notes to the Federal Reserve Bank of New York

13. The opportunity cost of holding excess vault cash is reduced by permitting the ECIs to carry the currency inventory on the books of the Federal Reserve. for destruction and recirculate fit new-series notes to the public. The Federal Reserve Bank of New York performs regular unannounced management reviews and operational audits to ensure that the ECIs comply with legally binding agreements to safeguard the integrity of the process.

\section{IMPLICATIONS OF THE U.S. DOLLAR AS A GLOBAL CURRENCY}

\section{Increase in Interest Income}

The asset counterpart to the Federal Reserve liability for currency in circulation takes the form of securities of the U.S. Treasury and government-approved enterprises (Treasury and federal agency securities represented 97.6 percent of the total collateral for currency in circulation at the end of 2000). Thus, the Federal Reserve issues non-interest-bearing obligations (currency) and uses the proceeds to acquire interestbearing assets. The excess of the earnings that the Federal Reserve accrues from these interest-bearing financial assets, above Federal Reserve System expenses and the provision of capital, is remitted annually to the Department of the Treasury. As currency in circulation has increased in response to growing demand for U.S. currency abroad, interest earnings have also increased (chart 5). For 2000, the securities counterpart to Federal Reserve notes earned $\$ 32.7$ billion in interest income.

Because the value of currency in circulation changes daily, the Federal Reserve Banks monitor and report changes in net payments to the Board. Net payments represent the difference between the amount of currency that the Reserve Banks pay to and receive from commercial banks. If net payments are positive, the Federal Reserve will typically purchase securities through open market operations in an amount equal to the net increase of currency in circulation to offset the monetary policy implications of the drain on depository institutions' balances held at the Reserve Banks. Similarly, if net payments are negative, the Federal Reserve will typically sell securities in an amount equal to the decrease of currency in circulation.

\section{Counterfeiting Activity}

The U.S. Secret Service was established in 1865 to suppress counterfeiting activity in the United States. During the free banking era (1837-1863), state bank notes became the chief form of paper currency, and 
5. Currency in circulation and Federal Reserve interest earnings on U.S. Treasury securities and on federal agency securities, 1986-2000

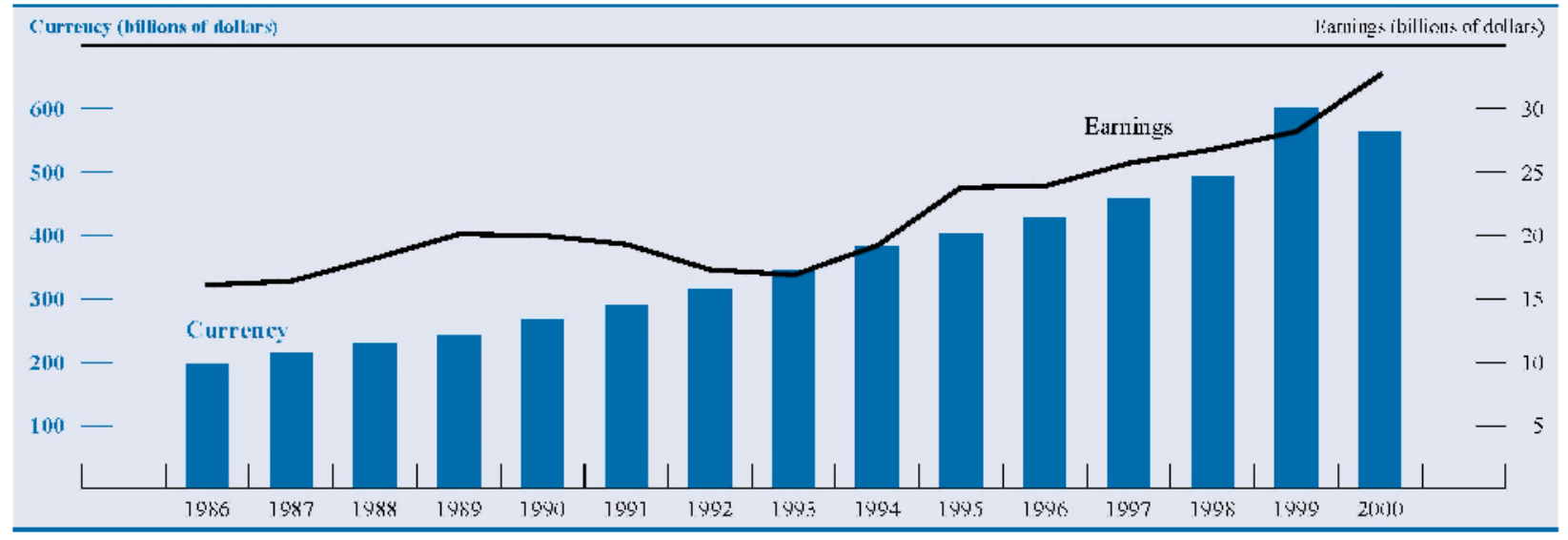

each state-chartered bank could issue currency with its own design. Because there was neither a consistent design nor central control over currency issuance, this institutional arrangement created opportunities for counterfeiters to deceive the public. As a result, the Secret Service believes that during the free banking era, counterfeit currency circulated widely and may have made up as much as one-third of total currency in circulation.

The National Banking Act of 1863 required national banks to invest in federal bonds, which entitled the banks to issue bank notes equal to 90 percent of the value of the bonds (the bonds were deposited with the Department of the Treasury). In contrast to state bank notes, the national bank notes were uniform in design and were imprinted with the name and charter number of the issuing bank. These notes were printed and used in circulation until 1935.

The Federal Reserve Act of 1913 gave to the Federal Reserve central control over currency issuance, but the Congress gave responsibility for designing U.S. currency to the Department of the Treasury and established the Secret Service as a Treasury bureau to guard against counterfeiting activity. As the Federal Reserve and the Department of the Treasury gained control of the design and issuance of U.S. currency, counterfeiting activity declined and remained relatively low for nearly seventy years. Over time, however, as U.S. currency achieved a greater global presence and as advances in technology provided opportunities for counterfeiters, new counterfeiting threats emerged both domestically and internationally.

Today, the Secret Service categorizes counterfeit currency by domestic or foreign origin, by method of production, and by whether the counterfeits represent an actual loss to the public. Some counterfeits are seized by law enforcement agencies before they circulate, whereas passed counterfeits have gone into circulation and represent an economic loss to the public - specifically, the final holders of counterfeit notes (chart 6). While any economic loss to the public is unfortunate, the domestic loss has generally been small; in 2000 , for example, it represented only two-tenths of 1 percent of the total value of domestic currency in circulation, or about 15 cents per U.S. citizen.

Traditionally, counterfeiters have produced banknote forgeries with offset presses, which require considerable skill to operate and are expensive to purchase. As computer and reprographic technologies have improved, however, the skills required and costs associated with bank-note forgeries have declined significantly. At first, with advances in reprographic technology, unskilled counterfeiters were able to produce forgeries on color copiers. Fortunately, because such reprographic equipment is expensive and normally located in view of other office workers, volumes of counterfeits have tended to be relatively small. Nevertheless, in fiscal year 1995, the U.S. public lost $\$ 2.4$ million because of color-copier counterfeits.

The use of color copiers to counterfeit currency was not unique to the United States. Because of the pervasiveness of the problem, an international group initiated discussions with the color-copier industry to address possible solutions to the counterfeiting threat. The international group successfully negotiated a technical solution, which was implemented in colorcopier equipment, to recognize bank notes and prevent them from being copied. The technology has been highly effective in reducing color-copier coun- 
6. Foreign and domestic counterfeits passed and seized, fiscal years, $1995-2000$

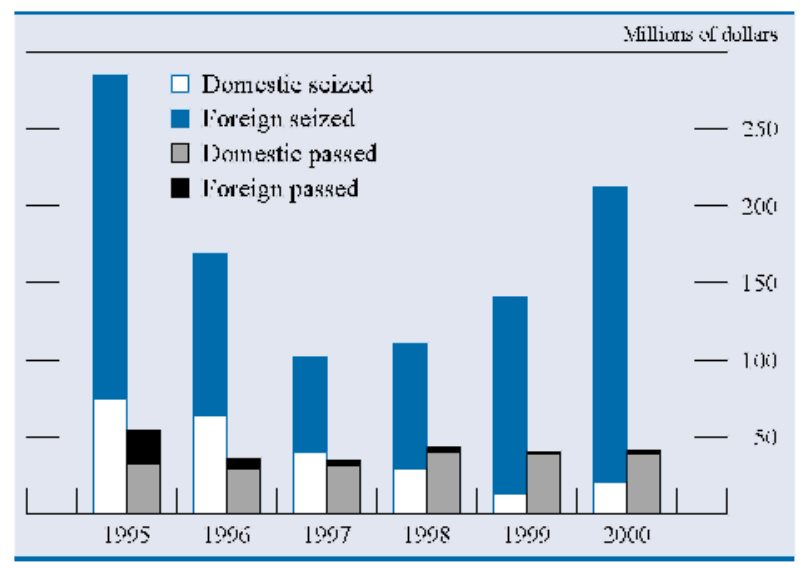

terfeiting, and in fiscal year 2000 , losses in the United States had fallen nearly 60 percent from their 1995 level, to $\$ 1$ million.

As the threat of counterfeits produced by reprographic equipment diminished, however, advances in personal computing technology increased opportunistic counterfeiting because personal computers and related peripheral equipment became affordable and widely available. The Secret Service defines counterfeits that are produced with personal computers (including scanners, image-editing software, and printers) as inkjet counterfeits. Since 1996, the proportion of inkjet counterfeits has grown from less than 1 percent of total passed counterfeits in fiscal year 1995 to nearly 50 percent in fiscal year 2000 .

Although U.S. currency includes features that are not easily reproduced with personal computers, the public lost about $\$ 20$ million in fiscal year 2000 from relatively poor-quality inkjet counterfeits. To supplement the existing anti-counterfeiting security features, the United States is cooperating in an international effort to devise technical solutions that will reduce the ability of the opportunistic counterfeiter to reproduce currency on personal computers.

The Federal Reserve and the Secret Service regularly monitor counterfeiting activity to ensure that the integrity of U.S. currency is not compromised. Although the Secret Service is the primary agency responsible for combating counterfeiting activity, the Federal Reserve also plays an important role in detecting highly deceptive counterfeit notes that pass unnoticed to the public. Reserve Banks also detect other counterfeit notes of varying quality. On average, depository institutions and the public detect about 80 percent of the total value of counterfeit notes passed and, as required by law, report the counterfeits to local police or the Secret Service. The
Federal Reserve Banks detect about 20 percent of passed counterfeits that are not detected by depository institutions or the public.

The Secret Service analyzes suspect notes that it receives from depository institutions, Reserve Banks, other law enforcement agencies, and the public and classifies them according to identifying characteristics that help to track notes (or families of notes) that come from the same producer. Fortunately, largely through an effective counterfeit-deterrent design and the efforts of the Secret Service, counterfeiting incidents are relatively low (the probability of the public's receiving a counterfeit U.S. note is about one in 10,000), and public confidence in U.S. currency remains very high.

\section{CURRENCY DESIGNS AS A DETERRENT. TO COUNTERFEITING.}

The basic design of the Series-1929 Federal Reserve note required very few security features. The distinctive feel of genuine currency paper, the raised surface that results from intaglio printing, and the red and blue security fibers were sufficient as low-level security features to deter counterfeiting. ${ }^{14}$ Although counterfeiting activity existed during this period, the threat was not significant, and the overall risk to the public was relatively inconsequential.

During the 1980s, the Department of the Treasury and the Federal Reserve recognized that U.S. currency was vulnerable to counterfeiting and commissioned a private consulting firm to evaluate the impact of emerging imaging technologies on the counterfeiting of U.S. currency. The study concluded that graphic arts and reprographic imaging systems might eventually pose a serious counterfeiting threat. ${ }^{15}$ In response to both the study's findings and independent work that the Federal Reserve conducted, the Department of the Treasury approved a new-series design in 1990. The Series-1990 currency incorporated a security thread and microprinting as visual counterfeit-deterrent features that the public could use to authenticate genuine currency and that were difficult to replicate with reprographic imaging systems.

14. Intaglio is a printing process in which the printing plate is recessed by engraving or etching on a metal plate. The printing takes place at very high pressure - up to 100 tons per square inch. The compression of the paper and the transfer of a thick layer of ink give an intaglio print its characteristic feel.

15. Sheldrick, J.E. et al., The Impact of Emerging Imaging Technologies on Counterfeiting of U.S. Currency (final report to the Board of Governors of the Federal Reserve System prepared by Battelle Columbus Laboratories, Columbus, Ohio, August 16, 1983). 
At the time, the Department of the Treasury and the Federal Reserve recognized that the security features of the Series-1990 design were insufficient to protect U.S. currency against counterfeits produced with highly sophisticated and technologically advanced reprographic and personal computing systems. To address the problem, a task force composed of representatives from the Department of the Treasury (including the Secret Service and the BEP) and the Federal Reserve System investigated possible solutions and recommended new currency designs that incorporated more sophisticated security features. As part of its evaluation, the task force investigated features that would be easily recognized by the public and other less visible features that would be difficult to replicate with the emerging technologies.

The Series-1996 design was the first major redesign of U.S. currency in nearly seventy years and included both a different look that was intended to attract public attention and sophisticated security features that would thwart the new counterfeiting threats. ${ }^{16}$ The Series-1996 design incorporates a security thread that, depending on denomination, glows in different colors under UV light and is located in different places on the note. The new design includes microprinting and other fine-line printing that is difficult to replicate on digital-imaging equipment. Features that are highly recognizable to the public include the larger, slightly off-center portrait that contains considerably more detail than portraits on older designs, a watermark depicting the figure in the portrait, and color-shifting ink on the front bottom right corner of the note, which changes from green to black when viewed at different angles.

In the face of continuing technological advances that will pose future challenges to U.S. currency, the Department of the Treasury and the Federal Reserve anticipate that they will need to recommend more frequent currency design changes to the Secretary of the Treasury in the future. Since the introduction of Series-1996 currency, the overall value of counterfeit notes passed has remained fairly constant at about $\$ 40$ million annually. Nevertheless, inkjet counterfeiting has become more prevalent, a development that has motivated policymakers to evaluate new design proposals. The BEP's goal is to have the next-generation currency ready for introduction as early as 2003 .

16. See Theodore E. Allison and Rosanna S. Pianalto, "The Issuance of Series-1996 \$100 Federal Reserve Notes: Goals, Strategy, and Likely Results," Federal Reserve Bulletin, vol. 83 (July 1997), pp. 557-64.

\section{PUBLIC EDUCATION ON CURRENCY REDESIGN}

Over the past ten years, U.S. currency has incorporated increasingly more complex security features. The new designs have features that an informed public can easily recognize, medium-security features that retailers and other cash handlers can use to authenticate currency, and high-security features that only the central bank and the Secret Service can use to authenticate currency. For the Series-1996 design, the Department of the Treasury developed and distributed educational material throughout the United States and the world. The goal of the educational material was to inform users of U.S. currency about the design changes to facilitate a smooth transition to the redesigned currency. Furthermore, the campaign explained the reasons for the redesign, familiarized cash handlers and users with the new features, and assured foreign users that there would be adequate supplies of the redesigned currency and that previous designs would remain legal tender.

As the United States moves forward with new designs, public education programs will need to inform even larger segments of the public about the features of genuine currency. Despite the Department of the Treasury's efforts thus far to direct the public's attention to the features in new designs, poor-quality inkjet counterfeits are easily passed to the domestic public. As the Department of the Treasury introduces new currency designs in the future, it must also commit adequate resources to prepare and deliver effective public education and awareness programs. The goal of these programs should be to improve the public's knowledge about the distinctive feel of genuine U.S. currency and the full array of overt security features. (See box "Introduction of the Euro and Public Education.")

In Section 807 of the Antiterrorism and Effective Death Penalty Act of 1996, the Congress imposed a requirement on the Department of the Treasury to report to Congress every three years through 2006 on the use and counterfeiting of U.S. currency abroad. ${ }^{17}$ In complying with this requirement, which is aimed at maintaining the integrity of and public confidence in U.S. currency worldwide, the Department of the Treasury and the Federal Reserve established the International Currency Awareness Program (ICAP). Although ICAP was initially established to aid the international introduction of the Series-1996 cur-

17. See U.S. Department of the Treasury, The Use and Counterfeiting of United States Currency Abroad (a report to the Congress by the Secretary of the Treasury, in consultation with the Advanced Counterfeit Deterrence Steering Committee, pursuant to section 807 of PL 104-132; Department of the Treasury, January 2000). 


\section{Introduction of the Euro and Public Education}

On January 1, 2002, the European Central Bank (ECB) will introduce the euro as the official national currency and coin for participating European Union (EU) countries. Each of the twelve participating countries (Austria, Belgium, Finland, France, Germany, Greece, Ireland, Italy, Luxembourg, the Netherlands, Portugal, and Spain) may co-circulate national bank notes and coins and the euro until February 28, 2002. Each participating country has determined for how long (usually through December 31,2002 ) its citizens can exchange national bank notes and coins at depository institutions. Thereafter, national bank notes and coins can be redeemed only at branches of the ECB.

The introduction of 14.3 billion euro bank notes and 50.1 billion euro coins has prompted the ECB to launch a massive public education effort, at a cost of about $€ 80$ million (\$69 million), called the Euro 2002 Information Campaign. The campaign will concentrate on four primary issues relating to the new bank notes and coins: (1) design features, (2) public security features, (3) denominations, and (4) details of the changeover from national bank notes and coins to euros. Accordingly, the ECB's campaign will attempt to eliminate questions and confusion by delivering throughout the EU a consistent message, which will include the following information:

- The euro will be physically available on January 1 , 2002.

- The bank-note designs for participating countries are identical

- The eight euro coins will have twelve versions, each with a national design of a participating country on one side and a common EU design on the other side.

- The bank notes have state-of-the-art security features.

- The decisions about how long each country's citizens can take to trade in their national bank notes and coins at central bank branches (after the co-circulation period) will be communicated.

The ECB's campaign is intended to reach the widest audience possible, including partners in the changeover effort, such as banks, retailers, tourism agencies, and many other businesses.

rency design, its goals now include quantifying the amount of genuine and counterfeit U.S. currency circulating abroad. ICAP representatives conduct interviews with high-level contacts in foreign banking organizations and law enforcement agencies and assess regional and local capabilities of detecting counterfeit U.S. currency.

\section{FUTURE OF BANK NOTES'AND COIN}

In 1999, the Department of the Treasury and the Federal Reserve Board studied the future of U.S. currency and coin in the United States and abroad and identified the components that drive demand for notes and coin.

Domestically, increases in aggregate spending will lead to continued increases in the demand for currency. New coin programs, such as the 50 States Quarter Program, are likely to continue to promote the growth of coin in circulation. The increasing use of alternative payment mechanisms might, however, reduce demand for currency and coin. For example, if the public chooses to make relatively greater use of credit or debit cards in place of cash, demand for cash will accordingly decrease. Smart card and storedvalue card technology may eventually become popular payment mechanisms, but their market niche is unclear at this time.

Internationally, any further steps toward dollarization in various countries would increase demand for U.S. currency. The effect of the euro on future demand for U.S. currency and coin, however, is not clear. Nonetheless, as long as foreigners continue to demand U.S. currency as a hedge against political and economic risk, the Federal Reserve can expect to see increased demand for Federal Reserve notes.

\section{CONCLUSION.}

The role of the Federal Reserve has expanded to accommodate increasing global demand for U.S. currency, and the Federal Reserve has instituted new policies and programs to effectively issue and distribute currency around the world. The Federal Reserve also cooperates with interagency groups that include the Department of the Treasury (including the Secret Service and the BEP) and international organizations to find solutions to complex currency issues that include currency management and counterfeit suppression.

Like all central banks, the Federal Reserve understands that in the current environment, emerging technologies will continue to present new opportunities for counterfeiters. For this reason, the Department of the Treasury and the Federal Reserve recognize that currency will need to be redesigned more frequently. U.S. currency, however, remains highly secure, and the value of passed counterfeits remains relatively low compared with the overall value of currency in circulation. The Federal Reserve and the Department of the Treasury will continue to assess counterfeiting threats and devise solutions to maintain confidence in the integrity of U.S. currency. 